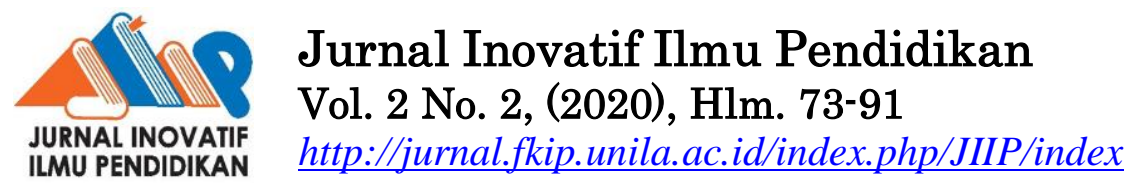

\title{
Analysis of School Conflicts Involving Parents: Experiences and Resolution
}

\author{
Delio B. Sannadan ${ }^{1}$, Claribeth B. San Pedro², Lourdes Myla T. Velchez ${ }^{3}$, \\ Ariel C. Venida ${ }^{4}$ \\ ${ }^{1}$ Head Teacher I, Amsic Integrated School \\ ${ }^{2}$ Master Teacher I, San Lorenzo Ruiz Elementary School \\ ${ }^{3}$ Head Teacher I, Dela Paz National High School \\ ${ }^{4}$ Teacher II, Bical High School \\ Purok 3, Amsic, Angeles City, Pampanga, Filipina \\ E-mail: riell12612@gmail.com
}

Article Info
Received Agustus 2020
Accepted September 2020
Published Oktober 2020

Keywords:

conflicts, learners,

negligence, parents, physical violence, sexual violence.

\section{Abstract}

Stakeholders' partnership in schools is a key factor in delivering a relevant, enabling, and responsible education to the learners. However, in the course of establishing this partnership, conflicts arise inevitably. The main objective of the study was to examine the prevalence of conflicts in schools that involve parents through a document analysis. A total of ten online cases were analyzed and served as the primary sources of data in this study. Coding was done to determine the emerging themes in each case. The analysis revealed that sexual and physical violence committed by a teacher or school official towards the learner; and negligence of duty which resulted in damage to the learner were the common sources of conflict. This suggests that parents' involvement in the issues is something favorable as apparently parents are expected to be the protectors and defenders of their children especially in times when children's rights and welfare are at stake or violated. The findings further revealed that in most conflicts, the learners were mostly offended while teachers and school authorities were mostly offenders. This finding suggests that children, even in school or under the custody of the teachers and school authorities, are still vulnerable to any form of violence and danger; and sometimes become helpless and defenseless especially when the persons who they expect to protect them become the aggressors. The finding also revealed that the learners mostly favored the court's decision. This conveys that in every court ruling, it is still the best interest of the children which is being given the foremost considerations. The implications from the findings of the study may inform the higher authorities in the Department of Education on how such conflicts will be prevented from happening. Also, based on the findings, it is recommended that the education department should take further actions in strengthening the implementation of the Child Protection Policy to keep every learner well-informed of their rights and make every stakeholder aware of their duties and responsibilities in promoting the well-being and education of the learners.

C2020 Jurusan Ilmu Pendidikan, FKIP Universitas Lampung 


\section{INTRODUCTION}

Stakeholders are an integral part of any organization. In the context of education, the positive impact of stakeholders' involvement as one of the key determinants of learners' success and schools' overall effectiveness, sustainability and improvement cannot be set aside (Gichohi, 2015; Tinker, 2015; National Education Association [NEA], 2008). The involvement of civic societies, communities, parents, and other stakeholders plays a vital role in providing every learner a quality education (United Nations Educational, Scientific and Cultural Organization [UNESCO], 2014). A well-established school-familycommunity partnership has been proven to improve school programs, parent's services, commitment, and leadership skills, and has been proven to contribute to building a welcoming and enabling school climate that is necessary to learners and the school's success (Epstein, 2011). Hence, strengthening a strong and healthy stakeholders' partnership and collaboration is undeniably important in achieving the best educational outcomes.

Nthontho (2017) stated that any individual or group who looks after the welfare and development of any organization and supports in any means to make this organization successful is a stakeholder. Stakeholders can be internal or external. Internal stakeholders are those entities who work within the organization and have a direct involvement on the operations of the system, while external stakeholders are those entities who are not working within the organization and not directly involved in the operations but have a strong concern on the performance of the organization (Paine, McCann \& U.S. Department of Education, 2009). In the context of education, the internal stakeholders include the learners, teachers, non-teaching personnel, administrators, and higher officials. On the other hand, external stakeholders refer to the members of the community which include the parents, barangay officials, local government units, private companies, religious groups, civic society groups, and other non-governmental organizations (David, 2016).

Both internal and external stakeholders are vital in attaining the goals of the schools (David, 2016). More specifically, a parent-teacher partnership which is proven to be very strong suggests a positive effect on students' performance in school. Also, parents who are involved in the school activities of their children 
feel more assured of the positive education process of their children. Therefore, school administrators who highly encourage parents' participation guarantees higher achievement of the school's vision, mission, and goals (Ntekane, 2018). Nonetheless, although effective partnerships with stakeholders particularly with parents could lead to better school performance and students' achievement, establishing and sustaining a harmonious relationship among stakeholders remains to be a challenging task because of some conflicts that arise among and between them (Lasater, 2016).

The prevalence of conflict in an organization is normal and inevitable. Every member of the organization has a unique personality and therefore has his/her way of viewing things (Cadiz, Villena, \& Velaso, 2016). Failure to find a common ground for these contrasting ideas creates friction which leads to conflict (Dogan, 2016). In the school setting, conflicts may arise between teachers and parents (Lasater, 2016), parents and school principals (Icutan \& Sagaoinit, 2017), teachers and teachers, teachers and students, students and students and schools and their community (Opoku-Asare, Takyi1 \& Owusu-Mensah 2015). Conflict may either affect the organization positively or negatively. Conflicts may generate negative emotions like demotivation, discouragement, sadness, and anxiety. It may also lead to decreased cooperation and productivity among the members of the organization. On the other hand, conflicts may result in understanding behavior and may also result in improved communication, creativity in finding solutions to problems, and enhanced organizational performance (Göksoy \& Argon, 2016).

A considerable number of researches have been already conducted in foreign institutions that identified the causes of these conflicts. One of them was the study conducted by Opoku-Asare, et al. (2015) which identified causes of conflicts in Ghana's primary schools. The findings of the study revealed that conflicts among learners arise due to improper actions such as bullying and theft while conflicts between parents and teachers are often associated with a simple miscommunication to more serious reasons such as exchange of offensive and insulting words and corporal punishment inflicted by the teacher to the student. Also, conflicts among teachers are often related to issues such as competition, debt, and mocking and while conflicts between teacher and learner are often linked to actions such as disobedience, disrespect, and lying. It was further 
revealed from their study that conflicts among teachers and head teachers are related to lack of respect, gossiping, partiality and absenteeism while conflicts between the school and community are often linked to corruption such as mismanagement of school properties.

In the Philippines, although the importance of school-family-community partnership and collaboration among different stakeholders to deliver the best quality basic education to all Filipinos is being emphasized by the Philippine Education Department (Philippine DepEd, 2018), still several incidents of conflicts are being reported among its stakeholders, particularly those that involve parents, teachers and school officials. One of which was the issue of a teacher who was suspended while under investigation by the DepEd after being reported by one parent of allegedly asking for a television from students who failed in her subject (Balagtas, 2016). Serious cases were also evident in the news which includes a teacher who faced administrative and criminal cases after being complained by parents of allegedly slapping 8 male students who bullied one of their female classmates ("Teacher Charged for Slapping 8 Students," 2015). The most recent incidence of conflict among stakeholders is the issue of a teacher who was complained by a parent and brought to public attention due to allegedly disciplining her student by sending him out of the classroom (Ronda \& Mateo, 2019). Because conflicts come in a variety of forms and reasons and only a few studies in the Philippine setting have dealt on this issue, this study attempted to examine the prevalence of conflicts in schools involving stakeholders particularly those that involve parents, teachers and school officials who are considered to be the primary stakeholders in education using cases filed in courts. Specifically, this research sought answers to the following questions: : (1) what are the common sources of conflict in school that involve parents; (2) who is mostly the offended and the offender; (3) who mostly favors the court's decision; and (4) what implications can be acquired from the findings of the study? The implications from the findings may serve as useful inputs in informing the DepEd in developing relevant policies or strengthening the implementation of an already existing policy for an improved delivery of education. 


\section{METHODOLOGY}

Document Analysis was the research method employed in this study. In a journal article entitled Document Analysis as a Qualitative Research Method, Bowen (2009) gave a detailed discussion on document analysis. He stressed that document analysis is a systematic procedure in reviewing or evaluating both printed and electronic documents. In events when data can no longer be recalled or recorded, documents are considered as the most effective means of gathering data. This qualitative research method requires a thorough examination and interpretation of the document to uncover meaning and get information from the documents which are relevant to the research questions. Although document analysis is often employed together with other qualitative methods as a way of substantiating and validating data acquired from other methods or sources, this method can also be used as a stand-alone research method. Document analysis saves time and effort, so it is considered as one of the most effective and efficient methods among other qualitative research methods.

In this study, the researchers followed the different steps in conducting document analysis cited in the article of Bowen (2009). These steps include selecting the appropriate document to be analyzed, assessing and making sense of the document, synthesizing the information acquired from the document, organizing the information into categories and themes.

The data used in the study came from court ruling documents and newspaper articles publicly available online. To be able to identify the cases that were relevant, proper keywords such as cases involving parents and teachers, teacher-related cases were used for searching. All in all, ten documents were analyzed in this paper. Data privacy measures were taken into consideration by the researchers in conducting the study to ensure that the identity of the persons involved in each case will not be revealed.

\section{RESULTS AND DISCUSSION}

\section{Conflict between Parents and Teachers}

Parents and teachers are said to be partners in developing a child. However, there are times that they come into conflict with one another. The following are cases filed by parents against teachers. 
The first case was filed by the parent of a child who was raped by his teacher. The incident happened when the victim together with her two classmates was asked by the teacher to visit his house to do an errand. The case was proven by the medico genital report of the National Bureau of Investigation. A verdict of guilty beyond reasonable doubt and sentenced to permanent imprisonment for a crime rape was charged to the suspect. Also, to indemnify the victim, the suspect paid a certain amount as moral and exemplary damages fee under the ruling of Regional Trial Court.

The second case was about a parent who sued a teacher of slight physical injury. The said teacher slapped and choked the victim thinking that he the victim) was the cause of her (teacher) child's accident. After a series of reconsideration filed by the teacher, she was proven guilty beyond reasonable doubt of slight physical injuries where she was sentenced and penalized of one day to ten days of imprisonment from one day to thirty days as reflected in paragraph 2, Article 266 of the Revised Penal Code.

The third case was about a teacher sued by a parent and was found guilty of reckless imprudence resulting to homicide when one of her students was drowned in a swimming pool during a year-end celebration in her absence. The class adviser secured a permit from the principal that was approved, distributed and signed by the parents. However, one of the student's parents did not sign the consent but still brought their daughter to school. So, the class adviser assumed that the parents gave their permission to their daughter to join the party. The teacher was out because she needed to attend those two students who sneaked out. However, it was not an excuse for the negligence of duty. At the same time, the school dismissed the respondents from the service in which the respondent contested it in the court of appeals, but the court still favored the first decision.

The fourth case explained how a child was abused by his teacher. The child accidentally bumped into the teacher's knee. The teacher demanded for an apology from the child. Unfortunately, the child ignored his teacher which provoked the teacher to push him onto the floor. Eventually, the child lost his consciousness. Dismayed in what happened, the child reported to his parents what happened in class upon arrival at home and this prompted the parents to bring their child to the hospital. The teacher was proven guilty of child abuse. 
The fifth case was filed by the parent of the victim. It was about a teacher who was removed from the service after being found guilty of grave misconduct by sexually harassing his pupil. The facts of the case presented stated that the pupil went to the teacher's office to do a certain task. There, the teacher caressed and touched the victim's breast. The teacher denied the allegation by contesting that the incident happened just by accident. However, a witness testified that the incident really happened. Several motions for reconsideration was filed by the suspect. However, the first decision made on the case that the teacher sexually harassed his pupil and therefore, should not be allowed, under any circumstance to stay in the noble profession was affirmed.

\section{Conflict between Parents and School Officials}

Not all the time parents file cases against teachers, there are also instances they file cases against the school officials. The researchers identified cases filed against a school principal and the decision of the court.

The first case was an administrative case filed by parents against a school principal and school clerk. The latter were alleged of colleting unathorized fees and failing to remit and account the said fees for public fund. Adding to this case, another parent filed complaint against the same respondents cases of oppression, serious misconduct, discourtesy, physical and mental incapacitu or disability due to immoral or vicious habits. All these cases were denied though they were found guilty in the ombudsman.

The second case was a case filed by a parent against a principal due to negligence that resulted in the death of the pupil. Based on the fact presented, the pupil was walking along the perimeter fence of the school when a rotting branch of a dead tree located within the premise of the school fell on her causing her sudden death. The principal filed for a motion for consideration positing that she was not negligent because she didn't notice that the tree was dead and rotting, and she already commanded the person next-in-rank to her to dispose of the tree. But the Court of Appeals reiterated that as the principal, she should have known about the tree and should've done something no matter how busy she was. The mere fact that tree was already dead, and the rotting branches may fall was a clear danger that she should've foreseen as the overall in-charge of overseeing the maintenance of the school grounds and safety of the children 
within the school premises. The Court of Appeals denied the motion and ordered the principal to pay a certain amount for the life of the child, burial damages, and attorney's fees.

The third case involved a principal who was accused of raping a student, the said principal was given a verdict of guilty beyond reasonable doubt and was made to pay a certain amount for moral damages. The incident happened when the pupil went to the house of the principal to explain that her parents cannot make it in the school on the date as per ordered by the principal because he(principal) wanted to talk to her (victim) parents for the offense she committed.

The fourth case was about parents who filed a complaint against the Schools Division Superintendent and other supervisors due to expulsion of students who did not participate in giving salute and singing of the national anthem who happened to be members of a religious group wherein honoring flag is against their belief. As a result, after a thorough consideration, Supreme Court en banc, decided to favor wherefore, the petition to review the decision and prohibition is granted. The expulsion order issued by the public respondents against the petitioners was hereby annulled and set aside. The temporary restraining order which was issued by the court was hereby made permanent.

The fifth case was filed by a parent against the school, its officials and teacher on the violation of Article 2180 of the Civil Code. Based on the facts presented, the victim went to school to submit a requirement in a subject during a semester break so he will be included in the graduation list when one student came along and shot the victim that led to his death. After the trial, the court held the defendants liable to the victim. However, on the appeal that was made, the decision was reversed, and all the defendants were completely absolved applying the following conclusions: Though the formal classes had ended, the boy was considered killed while in the custody of the school authorities because of a legitimate purpose. However, none accused can be held liable because all of them were just exercising a general authority over the student during the incident and none of them had been found guilty of negligence concerning their custody. Also, the school itself can't be held responsible because it is an academic institution and not a school of arts and trades to which the law applies. The court, therefore, denied the petition without any pronouncement as 
to costs. But the suspect was convicted of homicide through reckless imprudence.

Table 1. Conflict between Parents and Teachers

\begin{tabular}{ccccc}
\hline Charges Filed & Category & Offender & Offended & Decision \\
\hline \hline Rape & $\begin{array}{c}\text { Sexual } \\
\text { Violence }\end{array}$ & Teacher & Student & Guilty \\
$\begin{array}{c}\text { Slight Physical } \\
\text { Injury } \\
\text { Reckless }\end{array}$ & $\begin{array}{c}\text { Physical } \\
\text { Violence }\end{array}$ & Teacher & Student & Guilty \\
$\begin{array}{c}\text { Imprudence } \\
\text { resulting to } \\
\text { Homicide }\end{array}$ & Negligence & Teacher & Student & Guilty \\
$\begin{array}{c}\text { Child Abuse } \\
\text { Sexual } \\
\text { Harassment }\end{array}$ & $\begin{array}{c}\text { Physical } \\
\text { Violence } \\
\text { Sexual } \\
\text { Violence }\end{array}$ & Teacher & Student & Guilty \\
\hline
\end{tabular}

Table 1 presents the cases filed in courts involving parents and teachers. As indicated in the findings, the conflicts that arose between the parents and the teachers were related to violence such as physical and sexual violence committed by a teacher towards a student; negligence which caused damage to the learner. The analysis also revealed that violence such as physical violence and sexual violence was the most common source of conflict between parents and teachers. Further analysis of the findings revealed that in most conflicts that arose between parents and teachers, the children or students/pupils were commonly the offended parties while the teachers are the offenders. Also, the findings have shown that in most cases, the court favored the students or pupils.

According to the National Baseline Study on Violence Against Children in the Philippines in 2015, there is a high prevalence of physical, psychological, sexual, and online violence committed on Filipino children and these are often committed by people of whom they trust. Despite the high incidence of violence, 7 in 10 children are not aware of services that may be able to help them (Philippine United Nations Children's Funds [UNICEF], 2015).

Furthermore, $80 \%$ of Filipino children have experienced some form of violence at home, in school, in their community and online. It was also stated that physical violence was the most prevalent form of violence in schools perpetrated by adults, with verbal violence the second most frequent and sexual harassment is the most frequent form of sexual violence in school settings, 
occurring in both primary and secondary schools, with girls being particularly vulnerable (University of the Philippines Manila, The University of Edinburgh, Child Protection Network Foundation and UNICEF Philippines, 2016).

In the case of the teacher who was charged with raping his student. The accused was found guilty beyond reasonable doubt of the crime of rape and hereby sentenced to suffer an imprisonment of reclusion perpetua (places a convict in prison from 20 to 40 years) and paid the victim a certain amount as moral damage fee. Meanwhile, the teacher who was found guilty of grave misconduct through acts of sexual harassment was dismissed from the service. First of all, the teachers' action contrasted with what the Republic Act No. 7836, known as the Philippine Teachers Professionalization Act of 1994, this law states that a teacher shall maintain at all times a dignified personality that could serve as a model worthy of emulation by learners, peers, and others (Philippine Teachers Professionalization Act, 1994). Secondly, the action of the teacher who was found guilty of sexual harassment was a clear violation of section 3(b)(4) of the Republic Act 7877 also known as the Anti-sexual Harassment Act of 1995 since the sexual advantage happened in the educational setting and resulted to an intimidating and offensive learning environment for the learner (Anti-Sexual Harassment Act, 1995).

In the case of the teacher who was found guilty of child abuse, it is very clear that the teacher violated Article VI, sec. 10 of the Republic Act 7610 known as Special Protection of Children Against Abuse, Exploitation and Discrimination Act which states that any person who shall commit any other acts of child abuse, cruelty or exploitation or to be responsible for other conditions prejudicial to the child's development including those covered by Article 59 of Presidential Decree No. 603, as amended, but not covered by the Revised Penal Code, as amended, shall suffer the penalty of prison mayor in its minimum period (Special Protection of Children Against Abuse, Exploitation and Discrimination Act, 1992). Furthermore, in another case where the court found the teacher guilty beyond reasonable doubt of the crime of slight physical injuries under paragraph 2, Article 266, of the Revised Penal Code, the teacher was sentenced to suffer the penalty of arresto menor (1 day to 30 days).

In the case of a student who was drowned in a swimming pool during a school party. The parent filed a case of reckless imprudence against the adviser 
and was later pronounced guilty of negligence of duty. Article VIII the Teacher and Learners Section 2 where it stated that a teacher shall recognize that the interest and welfare of learners are his first and foremost concern and shall handle each learner justly and impartially (Philippine Teachers Professionalization Act, 1994). Furthermore, the time that a child is enrolled in a school, the parent subjects the child under the direct authority and custody of that school. The school's administrators and teachers or any individual involved in taking care of that child then have the legal parental authority and responsibility for the underaged child while under their supervision, instruction or custody. This legal parental authority applies whether the child is outside or inside the school sites such as during work immersions and field trips, and during school hours or outside school hours such as during break times and flag ceremonies. Therefore, school officials and the teachers shall be held responsible for the negligence which led to any untoward incident or any form of injuries incurred by the child while under their care (The Family Code of the Philippines, 1987).

Table 2. Conflict between Parents and School Officials

\begin{tabular}{|c|c|c|c|c|}
\hline Charges Filed & Category & Offender & Offended & Decision \\
\hline Administrative & Corruption & Principal & Parent & Denied \\
\hline $\begin{array}{l}\text { Violation of the } \\
\text { Article } 2180 \text { of the } \\
\text { Civil Code }\end{array}$ & Negligence & Principal & Student & Guilty \\
\hline Rape & Sexual Violence & Principal & Student & Guilty \\
\hline $\begin{array}{l}\text { Expelling students } \\
\text { from their classes }\end{array}$ & $\begin{array}{c}\text { Abuse of } \\
\text { Discretionary of } \\
\text { Power }\end{array}$ & $\begin{array}{c}\text { Division } \\
\text { Superintendent } \\
\text { and } \\
\text { Supervisors }\end{array}$ & Student & Denied \\
\hline $\begin{array}{c}\text { Negligence causing } \\
\text { death of the } \\
\text { learner }\end{array}$ & Negligence & School Officials & Student & Absolved \\
\hline
\end{tabular}

Table 2 presents the cases filed in the court involving parents and school officials. The findings indicated that the common sources of these conflicts were mostly related to negligence of duty which resulted in damage to the learners. Negligence is defined as the failure to look at reasonable caution which ends up damaging to another and is assessed concerning the foreseeability of the danger that has occurred (Dietrich \& Field, 2019). According to Tomboc (2005), negligence is one of the most cited causes of damages in the education setting. 
She further noted that the possible bases of charges for negligence include civil liability by teachers and school officials due to injuries as a result of their own negligence; civil liability for damages caused by a person under their custody due to their failure in supervising them or due to their failure to take necessary precautions to prevent such injury from happening; civil and criminal liability by teachers and school officials for material damage due to own carelessness; subsidiary liability by crimes committed by the person while performing their duties under their supervision; and civil liability for breach of contract due to failure in taking necessary measures to secure student's life.

Other sources of conflicts between parents and school officials as revealed in the findings were related to corruption; and misconduct such as sexual violence committed by a school official towards a learner and abuse of discretionary power which led to the expulsion of the students. Corruption is a type of malpractice concerning abuse of power which is often associated with money such as the collection of unauthorized fees. Misconduct, on the other hand, is a type of unprofessional behavior that is judged by one's failure to adhere to the professional standards or code of ethics by a group where he/she belongs which includes sexual abuse and abuse of power (Calderon \& Ancho, 2018).

The analysis of the findings further revealed that in the cases of conflicts that arose between parents and school officials, learners were mostly offended while school principals and other school officials were mostly the offenders. The findings conveyed that school officials or persons in the authority who should always promote the welfare of the learners as part of their utmost responsibility sometimes fall short of their duty. The findings further indicated that if the learners are the ones being offended, the decisions of the courts most of the time favor them. This finding reflects what is stated in the DepEd order no. 40, series of 2012 referred to as the DepEd Child Protection Policy. According to this policy, the DepEd in partnership with its stakeholders shall ensure that every schools are positively contributing to the education and welfare of the children and also shall take with foremost consideration the best interest of the children in any decisions and actions that involve children, whether undertaken by public or private social institutions, courts of law, administrative authorities and law-making bodies in line with the principles articulated within the 
Convention on the Rights of kids of the United Nations. (Philippine DepEd, 2012). Moreover, under the 1987 Philippine Constitution, it is mandated that the state shall defend the right of children to assistance, including proper care and nutrition, and special protection from all forms of neglect, abuse, cruelty, exploitation, and other conditions prejudicial to their development (Philippine Constitution Article XV Section 3[2], 1987).

In the case of the students who were expelled by refusing to salute and give honor to the Philippine Flag despite the existence of the Republic Act No. 1265 which makes attending the flag ceremony to be compulsory and failure to adhere to these policies has a corresponding punishment such as dismissal (An Act Making Flag Ceremony Compulsory in Educational Institutions, 1955) it is clear in the provision of the Article III, section 5 of the 1987 constitution that freedom of religious expression and profession is basic right was violated (Philippine Constitution Article III Section 5, 1987). This freedom of religion among children was also given highlight in the article 14, section 1 of the Convention of the Rights of Child by the United Nations (UNICEF, n.d).

In the case of rape filed against a school principal, the DepEd's Child Protection Policy stated the department does not tolerate any act of child abuse, exploitation, violence, discrimination, bullying and other forms of abuse done by a teacher, administrator, and non-teaching personnel towards a child. Specifically, it does not tolerate violence against children which include any single act or repeated act of sexual ferocity such as but not limited to rape, sexual harassment, and the like (Philippine DepEd, 2012).

In the first case of negligence analyzed in this study, it is part of the principal's role as the overseer of the institution to ensure the school is the environment is safe for the learners as stipulated in the DepEd's mission ("The Philippine DepEd Mission,” n.d.) Also, the principle of res ipsa loquitur takes effect since the untoward incident would not have taken place due to the negligence of the principal who had the utmost control of the incident and even though there was no concrete evidence of negligence (Duru, 2012). With regards to the second case of negligence, though the court decided to deny the complaints of the petitioners due to lack of evidence that there was negligence on the part of the school officials and the teacher-in-charge and that the violation of the Article 2180 of the Civil Code was not applicable since the involved school is an 
academic institution, it is stated in the article 218 of the Executive Order no. 209, series of 1987 known as the Family Code of the Philippines, the school administrators and teachers, or any individual or institution directly involved in a child shall exercise their parental authority and responsibility over the child while he/she is under their instruction, supervision or custody (The Family Code of the Philippines, 1987).

In case of collection of unauthorized fees, it is a clear violation of the Republic Act 6713 also known as the Code of Conduct and Ethical Standards for Public Officials and Employees. As stated in article 2 of this law, public officials shall uphold a high ethical standard as a public servant and shall perform their duties with the highest standard of responsibility, integrity, proficiency, loyalty and shall uphold public interest over personal interest (Code of Conduct and Ethical Standards for Public Officials and Employees, 1989)..

\section{CONCLUSION}

Stakeholders are part of the educational system in the Philippines as well as any educational organization in foreign countries. They function in a way that they also involve themselves in high, competitive, and significant affairs of the students, teachers, and administration. Thus, they are viewed to be effective agents of relevant, responsible, and quality education. This confirms that education is not just the responsibility of the teachers and administrators in this modern time. It is more of shared responsibilities, more strategic policy implementation, and a deeper commitment of all administrators, teachers, students, and stakeholders. Furthermore, stakeholders' involvement in the educational institution is viewed to yield positive and stronger relationships that result in the effectiveness, sustainability, and development of the school, its programs, and commitment to serve the community, society, and the world. However, in the course of establishing this partnership, conflicts arise inevitably. When these conflicts are not properly addressed and resolved, they are forwarded to legal authorities and thus become cases.

Different cases were analyzed in this study which were mainly drawn from court cases and newspaper articles. The cases included in this study were group into two. The first group identifies cases filed in court as a result of conflicts that arose between parents and teachers. These cases include charges filed by 
parents against teachers such as rape, child abuse, and reckless imprudence resulting to homicide; and case filed by teachers against parents such as grave slander. The analysis revealed that these cases can categorized into physical violence, sexual violence, negligence, and defamation. As the results indicate, violence particularly physical and sexual violence are the most frequent source of conflict between parents and teachers. This implied that parents' involvement in the issues is something favorable as apparently parents are expected to be the protectors and defenders of their children especially in times when children's rights and welfare are at stake or violated.

The second group recounts charges filed by parents against school officials which include administrative case, rape, violation of the Article 2180 of the Civil Code of the Philippines, illegal expulsion of students and negligence. The analysis revealed that these cases can be further categorized into corruption, negligence, sexual violence and abuse of discretionary powers. The results show that negligence which caused damage to the learner was the most frequent source of conflict between parents and school officials. This conveyed that still, parents are at their plight of securing their children's welfare and upholding their rights as school officials tend to abuse their power and forget to fulfill their main duties and those are to protect and promote the right of every child under their care. As a whole, the result of this study stresses that sexual violence, physical violence, and negligence which resulted in damage to the learner are the most frequent sources of school conflicts that involve parents and learners.

Furthermore, the study has shown that regardless of the conflict arises between parents and teachers or parents and school officials, the offenders are generally the teachers and school officials while the offended are the students, while the court favors mostly the students over others. This indicates that students are predisposed to conflicts, violence, and abuse. Sometimes, they become helpless and defenseless especially when the persons who they expect to protect them become the violators or aggressors.

Based on the findings, it is evident that there is a call for strengthening the Child Protection Policy of the Department of Education where students' welfare is a primary importance. Students must be protected when they are abused, defended when their rights are violated and respected regardless of who they are. If this happens, teachers and school officials would know exactly the 
boundaries of the involvement and appreciate more of their roles as educators. While in the cases of negligence, it is also evident that teachers and school authorities should become more aware of their duties and responsibilities as the ones who were given the special parental authority over the learners who are under their care. They must become extra cautious and vigilant in supervising the learners who are subject to their custody.

Since conflicts arise inevitably in school settings, school administrators and staff must heighten their commitment to protect and promote the right of every Filipino student. Hence, if conflicts arise, they must seek a common ground to resolve these issues at hand at the local level. Also, since conflicts are brought about by either internal or external factors in the school and thus are inevitable, every educational institution must design programs that strengthen relationships between administrators, teachers' students, and parents; initiates and supports mutual respect and understanding.

\section{REFERENCES}

An Act Making Flag Ceremony Compulsory in Educational Institutions (1955). Retrieved from https://thecorpusjuris.com/legislative/republic-acts/ra-no1265.php

Anti-Sexual Harassment Act of 1995. Retrieved from https://pcw.gov.ph/law/republic-act-7877

Balagtas, A. (2016, June 17). DepEd suspends teacher who asked parents for tv. Inquirer.net. Retrieved from https://newsinfo.inquirer.net /791097/depedsuspends-teacher-who-asked-parents-for-tv

Bowen, G. (2009). Document analysis as a qualitative research method. Qualitative Research Journal, g(2), 27-40.

Cadiz, A. P., Villena, D. H., \& Velaso, A. H. (2016). A conflict management program for teachers. The Normal Lights, 10(2), 127-156.

Calderon, A. B. B. \& Ancho, I. V. (2018). Examining malpractice in the education context. Journal of Research, Policy \& Practice of Teachers \& Teacher Education, 8(2), 95-103.

Code of Conduct and Ethical Standards for Public Officials and Employees (1989). Retrieved from https://www.nia.gov.ph/sites/default/files/basic page/raNo_6713.pdf 
David, C. F. (2016). Meet our stakeholders. SunStar Pampanga. Retrieved from https://www.pressreader.com/philippines/Sunstar pampanga/20160220/281689728876689

Dietrich, J., \& Field, I. (2017). The 'Reasonable Tort Victim': Contributory negligence, standard of care and the 'equivalence theory'. Melbourne University Law Review, 41(2), 602-646.

Dogan, S. (2016). Conflicts management model in school: A mixed design study. Journal of Education and Learning, 5(2), 200-219.

Duru, O. W. Z. (2012). The applicability of the doctrine of res ipsa loquitur negligent actions: A critical appraisal. Retrieved from https://ssrn.com/abstract=2147373.

Epstein, J. L. (2011). School, family, and community partnerships: Preparing educators and improving schools (2nd ed.). Philadelphia, PA: Westview Press.

Gichohi, G. W. (2015). Stakeholder involvement in schools in 21st century for academic excellence. International Journal of Education and Research, 3(2), 13-22.

Göksoy, S. \& Argon, T. (2016). Conflicts at schools and their impacts on teachers. Journal of Education and Training Studies, 4(4), 197-205.

Icutan, S. L. S. \& Sagaoinit, C. S. (2017). Conflicts and resolutions of school administrators: Basis for innovative administrative program. Asia Pacific Journal of Contemporary Education and Communication Technology, 3(1), 247-260.

Lasater, K. (2016). Parent-teacher conflict related to student abilities: The impact on students and the family-school partnership. School Community Journal, 26(2), 237-262.

National Education Association. (2008). A NEA Policy brief: Parent, family, community involvement in education. Retrieved from http://www.nea.org/assets/docs/PB11 ParentInvolvement08.pdf

Ntekane, A. (2018). Parental involvement in education. Retrieved from https://www. $\quad$ researchgate.net/publication/324497851_PARENTAL_ INVOLVEMENT_IN_EDUCATION/link/5ad09062aca2723a33472c9f/down load 
Nthontho, M. (2017). Children as stakeholders in education: Does their voice matter. South African Journal of Childhood Education, 7(1), 1-7.

Opoku-Asare, N.A.A, Takyi1, H. and Owusu-Mensah, M. (2015). Conflict prevalence in primary school and how it is understood to affect teaching and learning in Ghana. Retrieved from https://creativecommons.org/licenses/by/3.0/

Paine, S., McCann, R. \& U.S. Department of Education. (2009). Engaging stakeholders: Including parents and the community to sustain improved reading outcomes. Retrieved from https://www2.ed.gov

Philippine United Nations Children's Funds (2015). National Baseline Study on Violence Against Children in the Philippines. Retrieved from https://www.unicef.org/philippines/reports/national-baselinestudyviolence-against-children-philippines

Philippine Constitution Article III Section 5 (1987). Retrieved from https://www.comelec. gov.ph/

Philippine Constitution Article XV Section 3[2] (1987). Retrieved fromhttps://www. comelec.gov.ph/

Philippine Department of Education (2012). DepEd Protection Policy (Department Order No. 40). Retrieved from https://www.deped.gov.ph/2012/05/14/do-40-s-2012-deped-childprotection-policy/

Philippine Department of Education (2018). Guidelines on the utilization of program support funds for partnership building and linkages for fiscal year 2018 (Department Order No. 7). Retrieved from http://www.depedmalaybalay.net/wpcontent/uploads/2018/02/memo-18127.pdf

Philippine Teachers Professionalization Act 1994. Retrieved from https://www.pcw.gov.ph/law/republic-act-7836

Ronda, R. A. \& Mateo, J. (2019, November 25). DepEd: Policy in place to address 'teacher shaming.' The Philippine Star. Retrieved from https://www.philstar.com/nation/2019/11/25/1971536/deped-policy-placeaddress-teacher-shaming

SunStar Philippines. (2015, December 3). Teacher charged for slapping 8 students. Retrieved from https://www.sunstar.com.ph/article/45866 
The DepEd Mission (n.d.). Retrieved from https://www.deped.gov.ph/about$\mathrm{deped/vision-} \mathrm{mission-core-values-and-mandate}$

The Family Code of the Philippines (1987). Retrieved from https://www.officialgazette.gov.ph/1987/07/06/executive-order-no-209-s$1987 /$

Tinker, R. (2015). Stakeholder schools: Why collaboration is key to the next phase of school reform. Retrieved from https://fabians.org.uk/wp/uploads/2015/09/ Stakeholder-schools-Sept-151-2.pdf

Tomboc, J.B. M. (2005). Liability issue: Torts and damages in education setting. DLSU Business and Economic Reviews, 15(2), 75-100.

UNICEF (n.d.). Convention of the rights of child. Retrieved from https://www.unicef.org/ child-rights-convention

United Nations Educational, Scientific and Cultural Organization. (2014). Education strategy 2014-2021. Retrieved from https://unesdoc.unesco.org/ark:/48223/pf0000231288 